\title{
Sex-related differences in markers of immune activation in virologically suppressed HIV-infected patients
}

\author{
Letizia Santinelli ${ }^{1,2+}$, Giancarlo Ceccarelli ${ }^{2 *} \mathbb{D}$, Cristian Borrazzo ${ }^{2}$, Giuseppe Pietro Innocenti ${ }^{2}$, Federica Frasca ${ }^{1}$, \\ Eugenio Nelson Cavallari ${ }^{2}$, Luigi Celani ${ }^{2}$, Chiara Nonne ${ }^{1}$, Claudio Maria Mastroianni ${ }^{2}$ and Gabriella d'Ettorre ${ }^{2}$
}

\begin{abstract}
Objectives: Gender-specific studies remain a neglected area of biomedical research. Recent reports have emphasized that sex-related biological factors may affect disease progression during HIV-1 infection. The aim of this study was to investigate the influence of sex on the levels of immune activation in the gut and in peripheral blood of individuals with HIV treated with fully suppressive antiretroviral therapy (ART).

Methods: Thirty individuals with HIV undergoing long-term fully suppressive ART were enrolled in this study. Lamina propria lymphocytes (LPL) and peripheral blood mononuclear cells (PBMCs) were isolated from gut biopsies collected by pancolonoscopy and peripheral blood samples. The expression of markers of immune activation was evaluated by multi-parametric flow cytometry. This is a sub analysis of ClinicalTrials.gov Identifier: NCT02276326

Results: We observed differences in the levels of immune activation in the gut and in PBMCs, with values higher in the gut compartment compared to PBMCs.

In addition, we found that the mean value of the levels of immune activation was higher in the women than in the men. Finally, we measured the markers of immune activation by mean relative difference (MRD) and confirmed the higher value in the women.

Conclusion: A significant sex-related difference in the level of immune activation was observed in a population of individuals with HIV on long-term ART. A more complete characterization of these differences may support the introduction of sex-specific approaches in the clinical management of individuals with HIV.
\end{abstract}

Keywords: HIV, Sex, Gut, PBMC, Immune activation

\section{Introduction}

In 2015, the National Institutes of Health (NIH) established that sex is a biological variable (SABV) to take into account for $\mathrm{NIH}$ funding and scientific publication [1]. This statement was based on scientific evidence that sex affects innate and adaptive immunity and results in

\footnotetext{
* Correspondence: giancarlo.ceccarelli@uniroma1.it

Letizia Santinelli and Giancarlo Ceccarelli should be considered equally first authors

2Department of Public Health and Infectious Diseases, Sapienza University of Rome, Rome, Italy

Full list of author information is available at the end of the article
}

sex-specific outcomes of autoimmune pathologies, malignancies, infectious diseases, and vaccines [2]. Indeed, a growing body of published studies illustrates that sex hormones play an important role in the regulation of the immune system by releasing cytokines involved in the proliferation, differentiation, and maturation of immune cells, therefore introducing the concept of immune dimorphism [3, 4].

In recent years, evidence has accumulated which demonstrates that the progression of inflammatory diseases, such as HIV infection, as well as the response to therapy,

(c) The Author(s). 2020 Open Access This article is licensed under a Creative Commons Attribution 4.0 International License, which permits use, sharing, adaptation, distribution and reproduction in any medium or format, as long as you give appropriate credit to the original author(s) and the source, provide a link to the Creative Commons licence, and indicate if changes were made. The images or other third party material in this article are included in the article's Creative Commons licence, unless indicated otherwise in a credit line to the material. If material is not included in the article's Creative Commons licence and your intended use is not permitted by statutory regulation or exceeds the permitted use, you will need to obtain permission directly from the copyright holder. To view a copy of this licence, visit http://creativecommons.org/licenses/by/4.0/. The Creative Commons Public Domain Dedication waiver (http://creativecommons.org/publicdomain/zero/1.0/) applies to the data made available in this article, unless otherwise stated in a credit line to the data. 
may be influenced by sex-related variables $[2,5,6]$. In particular, sex-related differences in the viral kinetics of HIV infection were described. Griesbeck et al. observed a different response to HIV during the acute infection, with women showing higher viral load and stronger antiviral response than men [5]. In contrast, several studies revealed lower viremia in the initial phase of chronic HIV infection in women as compared to men (over 40\% less circulating HIV RNA than men) [7]. These differences in virus replication during the initial phases of HIV infection could contribute to sex-related differences in the level of HIV-DNA in PBMCs. Moreover, higher levels of CD8+ T cell activation were found in untreated women with HIV-1 as compared to men and independent of the levels of plasma viremia [8]. Also supporting the impact of sex-related variables in HIV disease progression is the observation that woman have a 1.6-fold higher risk of developing AIDS [9]. Finally, changes in the levels of soluble markers of immune activation were reported in woman and men with chronic HIV infection, thus suggesting a potential predictive role in terms of HIV disease outcome [10].

In light of this information, studying the impact of sex-linked variables on the outcome of HIV infection and the response to antiretroviral therapy (ART) may improve the management of HIV infection. The aim of this study was to ascertain whether the levels of immune activation in the gut and peripheral blood are influenced by the sex of ART-treated HIV-1 positive patients with undetectable viremia.

\section{Methods}

The study was approved by the institutional review board (Ethics Committee of Umberto I General Hospital, Rome), and all participants signed written informed consent.

\section{Enrollment}

Thirty patients living with HIV (PLWH) treated with ART and virologically suppressed were recruited at the Department of Public Health and Infectious Diseases of "Sapienza" University of Rome (Italy). The inclusion criteria used to enroll HIV-positive patients were as follows: (i) to have signed the informed consent, (ii) men or women at least 18 years of age, (iii) on active ART, (iv) with HIV-1 RNA $<37$ copies $/ \mathrm{mL}$ and $\mathrm{CD} 4^{+} \mathrm{T}$ counts $>400$ cells $/ \mathrm{mm}^{3}$. Exclusion criteria were (i) history of or current inflammatory diseases of the small or large intestine; (ii) diarrhea; (iii) any current, past, or systemic malignancy; (iv) pregnancy.

This is a sub analysis of study identified as NCT02276326, registered on the ClinicalTrials.gov archive.
T-cell phenotyping by flow cytometry Sample collection and cell isolation

All individuals underwent a total colonoscopy and retrograde ileoscopy for at least $10 \mathrm{~cm}$ of distal ileum with conventional or slim scope (model CF or PCF-160 AI, Olympus Medical Europe GmbH, Hamburg, Germany). Specimens (two biopsies from each site) from the terminal ileum, cecum, ascending, transverse, and descending colon were obtained. Immune activation was evaluated in 60 biological samples (30 PBMCs and 30 gut biopsies). Moreover, the blood sample collection by venepuncture was performed in all subjects enrolled: whole blood was collected in vacutainer tubes containing ethylenediaminetetraacetic acid (BD Biosciences, San Jose, CA), and PBMC were separated by Ficoll gradient centrifugation (Lympholyte, Cedarlane Labs, Hornby, Ontario, Canada), followed by two washes in phosphatebuffered saline. PBMCs were used for immune phenotyping or cultured overnight for stimulation. Biopsies from intestinal sites were mixed with each other and processed. Briefly, biopsies collected in RPMI 1640 (heat inactivated $10 \%$ fetal bovine serum) were washed twice with EDTA wash media, resuspended, and incubated for $1 \mathrm{~h}$ at room temperature in EDTA solution $5 \mathrm{mM}$ on automatic shaker. Supernatant containing intraepithelial lymphocytes was removed, and biopsies were digested by 1 -h incubation at $37^{\circ} \mathrm{C}$ in pre-warmed RPMI 1640 (heat inactivated 10\% fetal bovine serum) with $1 \mathrm{mg} / \mathrm{mL}$ collagenase (Sigma-Aldrich, Milan, Italy) and $1.5 \mathrm{U}$ DNAse I (Sigma-Aldrich), bringing to the isolation of LPL, then filtered through a $70 \mu \mathrm{m}$ cellular strainer (Becton Dickinson).

\section{Surface marker staining}

PBMC and LPL were aliquoted in $1 \times 10^{6}$ cells $/ \mathrm{mL}$ and $250 \times 10^{3}$ respectively with RPMI medium plus $10 \%$ FBS (fetal bovine serum). Cells were stained with the specific mAbs, previously described, at dilution recommended by the manufacturer and incubated in the dark for $10 \mathrm{~min}$ at $4{ }^{\circ} \mathrm{C}$. The following anti-human monoclonal antibodies were added: CD3-PerCP, CD4-APC-Vio770, CD8-FITC, CD45RO-PEVio770, CD27-VioBlue, CD38APC, and HLA-DR-PE (Miltenyi Biotec, Bergisch Gladbach, Germany). The expression of markers of immune activation (CD38, HLADR) on naïve, central memory (CMEM), and effector memory (TEM) CD4 and CD8 Tcells was evaluated by multi-parametric flow cytometry (Table 1). Stained cells were previously washed in PBS, were acquired, and analyzed by Miltenyi Biotec flow cytometer-MACSQuant Analyzer (8 fluorescence channels, 3 lasers). Gating strategy and data analysis were conducted using the MACSQuantify software 2.5 (Miltenyi Biotec). At least 100,000 and 10,000 events in the CD3+ lymphocytes gate were analyzed for PBMCs and 
Table 1 CD4 and CD8 T-cell immunophenotyping and their biological functions

\begin{tabular}{|c|c|}
\hline & Function \\
\hline HLA-DR & $\begin{array}{l}\text { Critical for efficient antigen presentation to CD4+ T cells. } \\
\text { HLA DR is expressed primarily by antigen presenting cells and, together with CD38, is a useful marker of T-cell } \\
\text { activation following viral infection. }\end{array}$ \\
\hline CD38 & $\begin{array}{l}\text { Multifunctional ecto-enzyme involved in signal transduction, cell adhesion, and calcium signaling. } \\
\text { Used to study the processes of B- and T-cell differentiation and activation. Increased expression of CD38 on both } \\
\text { CD4+ and CD8+ T-cells in HIV-infected patients is associated with disease progression. }\end{array}$ \\
\hline CD27 & Important for the generation and long-term maintenance of immune response. Memory marker. \\
\hline CD45RO & $\begin{array}{l}\text { Regulator of T-cell antigen signaling. } \\
\text { Memory marker. }\end{array}$ \\
\hline $\mathrm{CD}_{2} 7^{+} \mathrm{CD} 45 \mathrm{RO}^{-}$ & Naïve cells recognize cognate antigen and initiate an immune response. \\
\hline $\mathrm{CD}_{2} 7^{+} \mathrm{CD} 45 \mathrm{RO}^{+}$ & $\begin{array}{l}\text { Central memory (CM) T-cells are activated in secondary lymphoid organs following recognition of antigen on DCs } \\
\text { and generate large numbers of effector cells. }\end{array}$ \\
\hline $\mathrm{CD}_{27^{-}} \mathrm{CD}^{2} 5 \mathrm{RO}^{+}$ & $\begin{array}{l}\text { Effector memory (EM) cells exhibit effector function immediately upon recognition of antigen presented on } \\
\text { non-professional APCS and limit the early spread of infection. }\end{array}$ \\
\hline
\end{tabular}

LPLs, respectively. Isotype controls were used as negative controls to differentiate non-specific background signal from specific antibody signal of CD38, HLA-DR markers.

\section{Cells activation and intracellular marker staining}

In order to evaluate intracellular IL-17 production, both PBMC and LPL were seeded with RPMI medium plus $10 \%$ FBS (fetal bovine serum) at $2 \times 10^{6}$ cells $/ \mathrm{mL}$ and $1.5 \times 10^{6}$ cells $/ \mathrm{mL}$ respectively. Cells were activated with ionomycin $(1 \mu \mathrm{g} / \mathrm{mL}$, Sigma-Aldrich) and phorbol myristate acetate (PMA) $(3 \mathrm{ng} / \mathrm{mL}$, Sigma-Aldrich) in presence of BD GolgiStop (Becton Dickinson).

Cells were incubated overnight at $37^{\circ} \mathrm{C}$ and $5 \% \mathrm{CO}_{2}$ and then harvested, permeabilized, and stained.

The following anti-human monoclonal antibodies were used: CD3-PerCP, CD4-APC-Vio770, CD8-FITC, CD45RO-PEVio770, CD27-VioBlue, IL-17-PE. Samples were acquired by Miltenyi Biotec flow cytometerMACSQuant Analyzer (8 fluorescence channels, 3 lasers). Gating strategy and data analysis were conducted using the MACSQuantify software 2.5 (Miltenyi Biotec).

\section{Virological analysis}

HIV-1 RNA copy numbers were evaluated in plasma samples collected from whole blood obtained in EDTAcontaining tubes and stored at $-80^{\circ} \mathrm{C}$. Combined with Siemens Healthcare's nucleic acid extraction technology, a HIV-specific quantitative reverse polymerase chain reaction (Versant kPCR by Siemens Healthcare Diagnostic Inc., Tarrytown, NY) was used to measure the levels of HIV-RNA. The detection limit is 37 copies/ $\mathrm{mL}$ [11].

\section{Statistical analysis}

All data were analyzed, and all graphs were generated using MATLAB version 7.9.0.529 (R2009b). The demographic characteristics of HIV-1 patients were compared using Mann-Whitney test. All measurements were taken as mean and standard error or median and range (IQR 75 th percentile, 25 th percentile). The mean relative difference (MRD) is defined as

$$
M R D=\frac{\Delta}{X_{2}}=\frac{X_{1}-X_{2}}{X_{2}}
$$

where $X_{1}$ is the measure of the peripheral blood marker, while $X_{2}$ is the measure of the marker referred to the gut. For values greater than the reference to the gut value, the MRD should be a positive number $(D>0)$ and for values that are smaller, the MRD should be negative $(D<0)$. The MRD with 1 sigma is uncertain on the meaning for each marker. The same test was also used to compare HIV-1-positive patients divided into two groups male and female, and to compare gene expression levels measured in PBMC and gut collected from patients with HIV-1. To assess the distribution, the Kolmogorov-Smirnov test and histograms were used. The same tests with group differences were tested using Student $t$ test or Mann-Whitney test for normally and non-normally distributed variables, respectively. The Fisher's exact tests or Chi-square tests were used as appropriate to test group differences of proportions. Univariable analyses were performed to determine which variables were significantly associated with sex on the HIV patients. Unstandardized mean difference (USMD) and their 95\% CIs were analyzed [12]. USMD has been computed as the difference between the follow-up in the men and women group, divided by the whole population variance. In all tests, the level of statistical significance was 0.05 .

Finally, all potential confounders were entered a regression model based on prior knowledge or expected clinical relevance. Analyses were performed with a stepwise forward regression model, in which each variable 
with a $p$ value $<0.05$ (based on univariate analysis) was entered the model; all regression models included age and gender at initial evaluation, as covariates.

\section{Results}

Demographic and clinical characteristics of HIV-1-positive patients

The study population $(n=30)$ was composed of 15 men and 15 women, with an average age of $47( \pm 8.7)$ years. Demographic and clinical characteristics of HIV-1infected, stratified by sex, are shown in Table 2. They were started on ART during chronic HIV-1 infection with a median $\mathrm{CD} 4 \mathrm{~T}$-cell count of 300 at the beginning of therapy (IQR 115-377). At enrollment, all subjects had been virologically suppressed $(<37$ HIV-1 RNA copies $/ \mathrm{mL}$ ) for at least 1 year, had a median CD4 T-cell count of 773 cells $/ \mathrm{mm}^{3}$ (IQR $623-950$ cells $/ \mathrm{mm}^{3}$ ), and had received therapy for a median of 11 years (IQR 519). Stratifying the study population by gender, men showed a mean age of 43 years $( \pm 10)$, a median duration of therapy of 6.5 years (IQR 1-17), and a median CD4Tcell count at enrollment of 667 (IQR 621-912), whereas women showed a mean age of 49 years $( \pm 5)$, a median duration of therapy of 14 years (IQR 11-23) and a median CD4 T-cell count at enrollment of 789 cells/ $\mathrm{mm}^{3}$ (IQR 708-918). No statistically significant differences between men and women were found in terms of demographics or clinical characteristics. Interestingly, the women enrolled had all reached menopause (clinically defined as "permanent cessation of menstruation occurred after 12 consecutive months of amenorrhea, for which there is no other obvious pathologic or physiologic cause") [13].
Levels of markers of immune activation in the gut and PBMCs

We measured 36 markers of immune activation expressed on CD4+ and CD8+ T cell in the gut and in PBMCs both in men and in women and found that for 23 markers the values were significantly higher in the gut than in PBMCs (Table 3). Representative flow cytometry plots, illustrating the gating strategy used for PBMC and LPL analysis, are shown in Fig. 1. When we considered these markers of immune activation expressed on CD4+ and CD8+ $\mathrm{T}$ cell only in the men, we observed that 33 markers of immune activation were higher in the gut compared to PBMCs, but only 19 markers showed a statistically significant difference as showed in Table 3. In the group of women, 34 markers were higher in the gut with respect to the PBMCs, and among these, 25 showed a statistically significant difference (Table 3 ).

Differences in immune activation markers: impact of sex Overall, in our study population, the levels of immune activation were higher in the gut than in the PBMCs (MRD value $-1.12 \pm 0.67$ )

When we analyzed activated immune cell types by sex, we observed statistically significant differences between men and women as reported in Table 4. Interestingly, ranked MRDs in women are often below the 0 line; hence, on average, the marker has a higher value in the gut than the peripheral blood, while in men the MRDs are on average equal to 0 (Fig. 2). A significant difference in the immunological response linked to sex was also highlighted by the lower average MRD value calculated for all markers in men $(-0.52 \pm 0.42)$ than in women $(-1.72 \pm 0.65)$.

Table 2 Demographic and clinical characteristics of HIV-1-infected

\begin{tabular}{|c|c|c|c|c|c|c|c|c|c|c|}
\hline \multirow[t]{2}{*}{ Parameters } & \multicolumn{3}{|c|}{ All population } & \multicolumn{3}{|l|}{ Female } & \multicolumn{3}{|l|}{ Male } & \multirow[t]{2}{*}{$p$ value } \\
\hline & Mean \pm SD & $\begin{array}{l}\text { Median } \\
\text { with IQR }\end{array}$ & $n(\mathrm{n} \%)$ & Mean \pm SD & $\begin{array}{l}\text { Median } \\
\text { with IQR }\end{array}$ & $n(\mathrm{n} \%)$ & Mean \pm SD & $\begin{array}{l}\text { Median } \\
\text { with IQR }\end{array}$ & $n(\mathrm{n} \%)$ & \\
\hline Age (years) & $45 \pm 8$ & $47(44-52)$ & - & $49 \pm 5$ & $51(45-52)$ & - & $43 \pm 9$ & $46(37-48)$ & - & 0.067 \\
\hline Gender (female) & - & - & $15(50)$ & - & - & - & - & - & - & - \\
\hline Smokers & - & - & $17(57)$ & - & - & $6(40)$ & - & - & $11(73)$ & 0.762 \\
\hline BMI (Kg/m2) & $23 \pm 3$ & $23(21-25)$ & & $22 \pm 4$ & $21(19-24)$ & & $23 \pm 2$ & $24(22-25)$ & - & 0.373 \\
\hline Race (Caucasian) & - & - & $29(97)$ & - & & $14(93)$ & - & - & $15(100)$ & 0.987 \\
\hline Years on ART (years) & $12 \pm 9$ & $11(5-19)$ & - & $17 \pm 6$ & $15(11-22)$ & - & $9 \pm 9$ & $5(1-15)$ & - & 0.012 \\
\hline $\begin{array}{l}\text { Years HIV diagnosis } \\
\text { (years) }\end{array}$ & $12 \pm 9$ & 11(5-19) & - & $17 \pm 6$ & $15(11-22)$ & - & $9 \pm 9$ & $5(1-15)$ & - & 0.014 \\
\hline CD4+ actual (cells $/ \mathrm{mm}^{3}$ ) & $744 \pm 299$ & $708(623-886)$ & - & $790 \pm 275$ & 789 (692-886) & - & $718 \pm 317$ & $667(623-825)$ & - & 0.560 \\
\hline CD4+ (\%) & $33 \pm 11$ & $34(30-38)$ & - & $38 \pm 5$ & $36(30-38)$ & - & $30 \pm 12$ & $32(24-37)$ & - & 0.032 \\
\hline $\begin{array}{l}\text { CD4+ nadir } \\
\left(\text { cells } / \mathrm{mm}^{3}\right)\end{array}$ & $283 \pm 223$ & 301 (74-382) & - & $182 \pm 144$ & $163(74-278)$ & - & $321 \pm 239$ & $322(109-522)$ & & 0.117 \\
\hline HCV infection & - & - & $3(10)$ & - & - & $1(7)$ & - & - & $2(13)$ & 0.922 \\
\hline $\begin{array}{l}\text { HIV-RNA actual } \\
\text { (copies/mL) }\end{array}$ & $<37$ & - & - & $<37$ & - & - & $<37$ & - & - & 1.000 \\
\hline
\end{tabular}


Table 3 Differences in immune-activation markers between the gut and PBMC

\begin{tabular}{|c|c|c|c|c|c|c|c|c|c|}
\hline & All (PBMC) & All (GUT) & & Male (PBMC) & Male (GUT) & & Female (PBMC) & Female (GUT) & \\
\hline Markers & Mean \pm SE & Mean \pm SE & $p$ value & Mean \pm SE & Mean \pm SE & $p$ value & Mean \pm SE & Mean \pm SE & $p$ value \\
\hline $\mathrm{CD}^{+}$naïve $\mathrm{CD} 8^{+}$ & $15.82 \pm 4.07$ & $18.92 \pm 3.70$ & 0.575 & $7.49 \pm 1.25$ & $17.79 \pm 3.02$ & 0.006 & $25.08 \pm 4.97$ & $20.18 \pm 4.51$ & 0.472 \\
\hline $\mathrm{CD}^{+}{ }^{+}$aïve $\mathrm{CD} 38^{+} \mathrm{HLA}^{-\mathrm{DR}^{+}}$ & $1.75 \pm 0.70$ & $8.97 \pm 1.92$ & 0.001 & $0.54 \pm 0.15$ & $9.59 \pm 1.68$ & 0.001 & $3.10 \pm 0.88$ & $8.28 \pm 2.26$ & 0.047 \\
\hline $\mathrm{CD4}^{+}$naïve HLA-DR ${ }^{+}$ & $4.97 \pm 2.21$ & $17.21 \pm 2.45$ & 0.001 & $2.56 \pm 0.46$ & $17.94 \pm 2.14$ & 0.001 & $7.65 \pm 2.95$ & $16.39 \pm 2.87$ & 0.044 \\
\hline $\mathrm{CD}^{+} \mathrm{TCM}_{\mathrm{CD}} 38^{+}$ & $10.89 \pm 2.71$ & $12.69 \pm 2.51$ & 0.628 & $10.14 \pm 0.77$ & $14.17 \pm 2.24$ & 0.108 & $11.72 \pm 3.75$ & $11.05 \pm 2.85$ & 0.889 \\
\hline $\mathrm{CD}^{+}{ }^{\mathrm{TCM}} \mathrm{CD} 38^{+}{ }^{+} \mathrm{LA}-\mathrm{DR}+$ & $1.47 \pm 0.23$ & $5.89 \pm 1.67$ & 0.014 & $1.5 \pm 0.20$ & $8.78 \pm 1.99$ & 0.003 & $1.44 \pm 0.59$ & $2.68 \pm 0.63$ & 0.164 \\
\hline CD4 ${ }^{+}$TCM HLA-DR+ & $2.94 \pm 2.88$ & $13.60 \pm 2.89$ & 0.012 & $7.34 \pm 2.16$ & $14.25 \pm 2.15$ & 0.032 & $6.12 \pm 1.17$ & $12.88 \pm 3.68$ & 0.100 \\
\hline $\mathrm{CD}^{+}{ }^{\mathrm{TEM}} \mathrm{CD} 38^{+}$ & $4.35 \pm 0.70$ & $10.50 \pm 2.03$ & 0.007 & $4.65 \pm 0.68$ & $11.03 \pm 1.88$ & 0.005 & $4.02 \pm 0.83$ & $9.91 \pm 2.29$ & 0.028 \\
\hline $\mathrm{CD}^{+}{ }^{+} \mathrm{TEM} \mathrm{CD} 38^{+}{ }^{+} \mathrm{HA}-\mathrm{DR}^{+}$ & $2.30 \pm 0.30$ & $6.02 \pm 1.32$ & 0.010 & $2.60 \pm 0.32$ & $6.26 \pm 1.56$ & 0.036 & $1.96 \pm 0.44$ & $5.74 \pm 1.08$ & 0.005 \\
\hline $\mathrm{CD}^{+}{ }^{+}$TEM HLA-DR ${ }^{+}$ & $11.96 \pm 1.26$ & $20.18 \pm 2.43$ & 0.005 & $11.52 \pm 1.08$ & $16.94 \pm 2.23$ & 0.041 & $12.46 \pm 1.77$ & $23.77 \pm 2.43$ & 0.001 \\
\hline $\mathrm{CD}^{+}$naïve $\mathrm{CD} 8^{+}$ & $12.45 \pm 3.31$ & $7.71 \pm 1.92$ & 0.223 & $5.99 \pm 0.76$ & $7.60 \pm 1.93$ & 0.448 & $19.63 \pm 3.94$ & $7.83 \pm 2.02$ & 0.015 \\
\hline $\mathrm{CD}^{+}{ }^{+}$aïve $\mathrm{CD} 38^{+} \mathrm{HLA}^{-\mathrm{DR}^{+}}$ & $1.36 \pm 0.35$ & $6.85 \pm 1.71$ & 0.004 & $0.76 \pm 0.15$ & $5.18 \pm 1.26$ & 0.004 & $2.02 \pm 0.43$ & $8.72 \pm 2.06$ & 0.006 \\
\hline $\mathrm{CD8}^{+}$naïve HLA-DR ${ }^{+}$ & $4.38 \pm 0.77$ & $21.68 \pm 3.87$ & 0.001 & $3.75 \pm 0.39$ & $17.33 \pm 1.57$ & 0.001 & $5.07 \pm 1.01$ & $26.52 \pm 5.25$ & 0.001 \\
\hline $\mathrm{CD}^{+} \mathrm{TCM}_{\mathrm{CD}} 38^{+}$ & $6.13 \pm 2.10$ & $9.72 \pm 2.16$ & 0.240 & $4.30 \pm 0.79$ & $10.42 \pm 2.07$ & 0.013 & $8.16 \pm 2.79$ & $8.94 \pm 2.36$ & 0.834 \\
\hline $\mathrm{CD}^{+}{ }^{\mathrm{TCM}} \mathrm{CD} 38^{+}{ }^{+} \mathrm{LA}-\mathrm{DR}+$ & $4.09 \pm 0.69$ & $9.32 \pm 2.22$ & 0.032 & $5.10 \pm 0.76$ & $9.83 \pm 2.26$ & 0.064 & $2.96 \pm 0.48$ & $8.74 \pm 2.31$ & 0.027 \\
\hline $\mathrm{CD8}^{+}$TCM HLA-DR+ & $8.54 \pm 1.51$ & $20.23 \pm 3.88$ & 0.008 & $8.81 \pm 1.58$ & $18.52 \pm 1.77$ & 0.001 & $8.24 \pm 1.45$ & $22.14 \pm 5.47$ & 0.027 \\
\hline $\mathrm{CD}^{+}{ }^{+} \mathrm{TEM} \mathrm{CD} 8^{+}$ & $6.50 \pm 2.56$ & $14.77 \pm 2.64$ & 0.029 & $3.74 \pm 0.40$ & $15.75 \pm 2.56$ & 0.001 & $9.57 \pm 3.49$ & $13.67 \pm 2.84$ & 0.372 \\
\hline $\mathrm{CD}^{+}{ }^{\mathrm{TEM}} \mathrm{CD} 38^{+}{ }^{+} \mathrm{HLA}-\mathrm{DR}^{+}$ & $4.25 \pm 0.58$ & $13.33 \pm 2.89$ & 0.004 & $4.11 \pm 0.57$ & $12.36 \pm 3.10$ & 0.020 & $4.41 \pm 0.60$ & $14.40 \pm 2.81$ & 0.003 \\
\hline CD8 $^{+}$TEM HLA-DR ${ }^{+}$ & $11.40 \pm 1.27$ & $19.88 \pm 3.55$ & 0.031 & $10.82 \pm 1.24$ & $15.08 \pm 1.89$ & 0.072 & $12.05 \pm 1.52$ & $25.21 \pm 4.50$ & 0.013 \\
\hline $\mathrm{CD}^{+}$naïve Th1 & $1.84 \pm 0.81$ & $5.26 \pm 2.05$ & 0.129 & $2.21 \pm 1.10$ & $2.09 \pm 0.87$ & 0.933 & $1.42 \pm 0.33$ & $8.78 \pm 2.61$ & 0.014 \\
\hline $\mathrm{CD4}^{+}$naïve Th17 & $0.01 \pm 0.01$ & $0.18 \pm 0.07$ & 0.030 & $0.01 \pm 0.00$ & $0.06 \pm 0.04$ & 0.203 & $0.01 \pm 0.01$ & $0.32 \pm 0.09$ & 0.005 \\
\hline CD4+ naïve Th1 Th17 & $0.13 \pm 0.02$ & $2.37 \pm 0.67$ & 0.003 & $0.13 \pm 0.03$ & $1.82 \pm 0.66$ & 0.023 & $0.14 \pm 0.02$ & $2.97 \pm 0.69$ & 0.001 \\
\hline $\mathrm{CD}^{+} \mathrm{TCM}$ Th1 & $10.87 \pm 3.41$ & $20.77 \pm 4.50$ & 0.086 & $9.38 \pm 3.93$ & $12.31 \pm 3.11$ & 0.564 & $12.53 \pm 2.91$ & $30.17 \pm 4.70$ & 0.004 \\
\hline $\mathrm{CD}^{+}$TCM Th17 & $0.06 \pm 0.02$ & $1.57 \pm 0.47$ & 0.004 & $0.03 \pm 0.01$ & $0.92 \pm 0.34$ & 0.023 & $0.09 \pm 0.03$ & $2.30 \pm 0.55$ & 0.001 \\
\hline CD4+ TCM Th1 Th17 & $0.46 \pm 0.11$ & $3.20 \pm 1.08$ & 0.018 & $0.38 \pm 0.10$ & $1.32 \pm 0.32$ & 0.015 & $0.55 \pm 0.13$ & $5.29 \pm 1.38$ & 0.004 \\
\hline CD4 ${ }^{+}$TEM Th1 & $15.03 \pm 4.39$ & $18.79 \pm 4.82$ & 0.567 & $10.92 \pm 4.67$ & $7.34 \pm 2.05$ & 0.491 & $19.59 \pm 4.00$ & $31.51 \pm 4.95$ & 0.073 \\
\hline CD4 ${ }^{+}$TEM Th17 & $0.13 \pm 0.04$ & $1.94 \pm 0.67$ & 0.012 & $0.07 \pm 0.03$ & $0.56 \pm 0.20$ & 0.039 & $0.2 \pm 0.05$ & $3.49 \pm 0.80$ & 0.001 \\
\hline CD4 $4^{+}$TEM Th1 Th17 & $0.49 \pm 0.13$ & $3.54 \pm 1.34$ & 0.032 & $0.26 \pm 0.06$ & $0.93 \pm 0.33$ & 0.073 & $0.74 \pm 0.16$ & $6.43 \pm 1.65$ & 0.004 \\
\hline $\mathrm{CD8}^{+}$naïve Tc1 & $7.99 \pm 2.70$ & $21.18 \pm 6.03$ & 0.053 & $5.87 \pm 2.65$ & $10.75 \pm 3.33$ & 0.263 & $10.33 \pm 2.77$ & $32.76 \pm 7.09$ & 0.009 \\
\hline CD8 ${ }^{+}$naïve Tc17 & $0.04 \pm 0.03$ & $0.27 \pm 0.10$ & 0.045 & $0.01 \pm 0.00$ & $0.10 \pm 0.03$ & 0.053 & $0.07 \pm 0.04$ & $0.46 \pm 0.13$ & 0.014 \\
\hline $\mathrm{CD}^{+}$naïve Tc1 Tc17 & $0.15 \pm 0.05$ & $0.99 \pm 0.42$ & 0.057 & $0.09 \pm 0.02$ & $0.51 \pm 0.16$ & 0.025 & $0.22 \pm 0.07$ & $1.53 \pm 0.57$ & 0.040 \\
\hline $\mathrm{CD8}^{+} \mathrm{TCM}$ TC1 & $26.81 \pm 7.59$ & $32.40 \pm 6.84$ & 0.587 & $19.82 \pm 7.73$ & $21.59 \pm 5.05$ & 0.849 & $34.58 \pm 7.33$ & $44.41 \pm 7.48$ & 0.357 \\
\hline $\mathrm{CD}^{+}$TCM Tc17 & $0.14 \pm 0.07$ & $0.36 \pm 0.12$ & 0.135 & $0.08 \pm 0.03$ & $0.21 \pm 0.09$ & 0.216 & $0.21 \pm 0.10$ & $0.53 \pm 0.14$ & 0.081 \\
\hline $\mathrm{CD}^{+}$TCM Tc1 Tc17 & $0.26 \pm 0.12$ & $0.51 \pm 0.14$ & 0.220 & $0.13 \pm 0.04$ & $0.33 \pm 0.11$ & 0.136 & $0.42 \pm 0.17$ & $0.71 \pm 0.16$ & 0.240 \\
\hline $\mathrm{CD8}^{+}$TEM TC1 & $26.30 \pm 7.46$ & $30.65 \pm 7.30$ & 0.678 & $18.13 \pm 7.81$ & $13.99 \pm 3.61$ & 0.636 & $35.37 \pm 6.70$ & $49.15 \pm 7.52$ & 0.183 \\
\hline $\mathrm{CD}^{+}$TEM Tc17 & $0.03 \pm 0.01$ & $0.29 \pm 0.14$ & 0.084 & $0.01 \pm 0.00$ & $0.12 \pm 0.10$ & 0.301 & $0.06 \pm 0.01$ & $0.47 \pm 0.17$ & 0.028 \\
\hline $\mathrm{CD8}^{+}$TEM TC1 Tc17 & $0.07 \pm 0.03$ & $0.44 \pm 0.15$ & 0.026 & $0.03 \pm 0.00$ & $0.30 \pm 0.13$ & 0.055 & $0.12 \pm 0.04$ & $0.59 \pm 0.17$ & 0.019 \\
\hline
\end{tabular}

Columns show marker name, mean \pm sigma values of each marker expressed in the gut and PBMC of all patients, men and women, $p$ value. The statistical significance is achieved when $p<0.05^{\dagger}$. Statistical differences between the gut and PBMC were evaluated using Student's $t$ tests

Finally, the sensitivity analyses, stratified by sex, looking at the relationship between the immune cell levels and duration of ART therapy (univariate analysis) is reported in Table 2. On the other hand, the multivariate analysis, stratified by sex, with duration of ART therapy along with potentially other HIV-related variables is presented in Table 5.

\section{Discussion}

While sex- and gender-specific research remains a relatively neglected topic in contemporary biomedical research, recent studies suggest that sex-related biological factors affect a number of physiological and pathological conditions. Under non-pathological conditions, Xchromosome, encoding for several genes involved in the immune regulation mechanisms, can potentially 


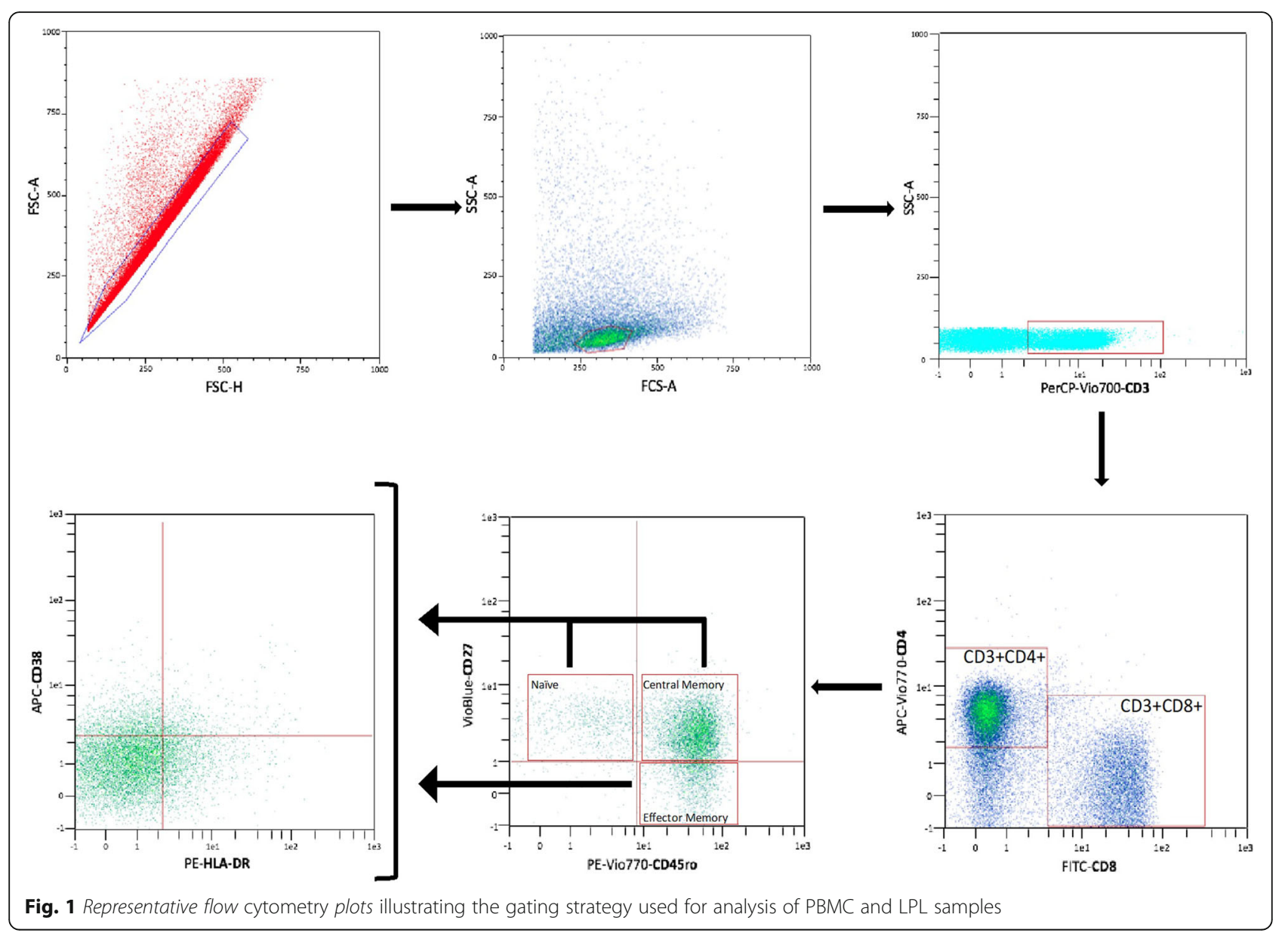

influence the immunocompetence. Moreover, steroid hormones play a pivotal role in immune modulation processes: in particular, estrogen receptors (ER) $\alpha$ and $\beta$ are ubiquitously expressed by immune cells and are involved with estrogen at different stages of maturation of immune cells and regulation of immune responses [14]. Sex-related differences in the activation status of the immune system were reported also in HIV-negative population affected by chronic pathologies: for example, from a general point of view, autoimmune diseases are more prevalent in women than in men and diseases course, severity, and survival may also differ by sex. Accumulating evidences suggest that if genetic, epigenetic, and environmental factors contribute to those sex-related differences, sex hormones play probably a pivotal role: in fact, estrogens would seem to represent a powerful stimulus towards autoimmunity while androgens would have a protective role [15]. In autoimmune diseases, men are known to respond to infections with a prevalent Th1 response, whereas women show a Th2 predominant immune response and an increased antibody production [16]. For example, a distinct sexual dimorphism was observed in the immune activation status of patients with systemic lupus erythematosus and ankylosing spondylitis, particularly in the Th17 axis $[17,18]$.

As previously reported, HIV infection on treatment can be assimilated to a chronic inflammatory disease and chronic inflammation and persistence of the state of immune activation can be considered hallmarks of HIV infection, also if successfully ART treated.

Natural history of HIV infection is characterized by a progressive dysfunction of cellular and immune responses and a disruption of the gut mucosal barrier with significant impairment of mucosal immune defense, mainly including CD4+ T cells and Th17 cells. The damage of mucosal lymphoid tissue gut and barrier contributes, with gut microbiome dysbiosis, to microbial translocation and takes part in persistent systemic activation of immunity. Chronic immune activation is considered a predictor of HIV disease progression and is mainly characterized by increased levels of type I interferons (TFNs), proinflammatory cytokines, and activation markers (including CD38 and HLA-DR) on both CD4+ and CD8+ T cells [19].

The availability of ART has dramatically decreased the risk for AIDS-related pathologies changing the natural 
Table 4 Differences in immune-activation markers between men and women

\begin{tabular}{|c|c|c|c|c|}
\hline & Markers & $\begin{array}{l}\text { Men } \\
\text { [MRD } \pm \\
\text { sigma] }\end{array}$ & $\begin{array}{l}\text { Women } \\
\text { [MRD } \pm \\
\text { sigma] }\end{array}$ & $p$-value \\
\hline \multirow[t]{18}{*}{ CD4+ } & CD4+ & $0.03 \pm 0.09$ & $0.11 \pm 0.06$ & 0.07 \\
\hline & CD4+ 38+ & $0.11 \pm 0.10$ & $-2.29 \pm 0.97$ & $0.024 \dagger$ \\
\hline & $\mathrm{CD} 4+38+\mathrm{DR}+$ & $0.47 \pm 0.10$ & $0.36 \pm 0.13$ & 0.053 \\
\hline & CD4+ DR+ & $0.19 \pm 0.16$ & $-0.37 \pm 0.83$ & 0.052 \\
\hline & CD4+ NAÏVE & $-6.38 \pm 1.19$ & $-5.36 \pm 1.24$ & 0.072 \\
\hline & $\begin{array}{l}\text { CD4+ NAÏVE } \\
\text { CD38+ }\end{array}$ & $0.05 \pm 0.35$ & $-1.28 \pm 0.21$ & $0.044 \dagger$ \\
\hline & CD4+ NAÏVE & $0.35 \pm 0.30$ & $1.62 \pm 0.09$ & $0.044 \dagger$ \\
\hline & CD38+DR+ & $1.61 \pm 0.06$ & $-0.61 \pm 0.06$ & $0.010 \dagger$ \\
\hline & CD4+ NAÏVE DR+ & $0.40 \pm 0.06$ & $0.45 \pm 0.05$ & 0.487 \\
\hline & CD4+ TCM & $-0.19 \pm 0.14$ & $-1.72 \pm 1.49$ & 0.324 \\
\hline & CD4+ TCM 38+ & $0.16 \pm 0.20$ & $-6.23 \pm 1.59$ & $0.035 t$ \\
\hline & $\begin{array}{l}\text { CD4+ TCM } \\
38+D R+\end{array}$ & $0.72 \pm 1.17$ & $-0.19 \pm 0.12$ & $0.047 \dagger$ \\
\hline & CD4+ TCM DR+ & $0.01 \pm 0.18$ & $-0.19 \pm 0.24$ & 0.523 \\
\hline & CD4+ TEM & $0.28 \pm 0.19$ & $-5.86 \pm 1.11$ & $0.033+$ \\
\hline & CD4+ TEM 38+ & $-1.23 \pm 0.55$ & $-0.32 \pm 0.81$ & 0.370 \\
\hline & $\begin{array}{l}\text { CD4+ TEM } \\
38+D R+\end{array}$ & $-1.40 \pm 0.52$ & $0.31 \pm 0.11$ & $0.007 \dagger$ \\
\hline & CD4+ TEM DR+ & $-0.15 \pm 0.08$ & $-0.38 \pm 0.11$ & 0.094 \\
\hline & CD8+ & $0.23 \pm 0.17$ & $-4.22 \pm 0.84$ & $0.027 \dagger$ \\
\hline \multirow[t]{14}{*}{$\mathrm{CD}^{+}$} & CD8+ 38+ & $-0.21 \pm 0.24$ & $-0.86 \pm 1.19$ & 0.060 \\
\hline & CD8+ 38+DR+ & $-0.16 \pm 0.23$ & $0.59 \pm 0.08$ & $0.010 \dagger$ \\
\hline & CD8+ DR+ & $-4.05 \pm 1.51$ & $-1.06 \pm 0.74$ & $0.010 \dagger$ \\
\hline & CD8+ NAÏVE & $-0.56 \pm 0.34$ & $-8.14 \pm 1.64$ & $0.024 \dagger$ \\
\hline & $\begin{array}{l}\text { CD8+ NAÏVE } \\
\text { CD38+ }\end{array}$ & $-0.29 \pm 0.61$ & $-6.21 \pm 2.91$ & $0.041 \dagger$ \\
\hline & CD8+ NAÏVE & $0.29 \pm 0.08$ & $0.76 \pm 0.04$ & 0.103 \\
\hline & CD38+DR+ & $0.48 \pm 0.08$ & $0.26 \pm 0.02$ & 0.243 \\
\hline & CD8+ NAÏVE DR+ & $0.05 \pm 0.29$ & $-4.92 \pm 1.09$ & $0.024 \dagger$ \\
\hline & CD8+ TCM & $-1.55 \pm 0.60$ & $-1.39 \pm 1.48$ & 0.923 \\
\hline & CD8+ TCM 38+ & $-0.05 \pm 0.18$ & $-1.68 \pm 1.06$ & $0.044 \dagger$ \\
\hline & $\begin{array}{l}\text { CD8+ TCM } \\
38+D R+\end{array}$ & $-0.29 \pm 0.19$ & $-0.61 \pm 0.30$ & 0.081 \\
\hline & CD8+ TCM DR+ & $0.28 \pm 0.21$ & $-7.99 \pm 0.80$ & $0.032 \dagger$ \\
\hline & CD8+ TEM & $-4.12 \pm 2.49$ & $0.43 \pm 0.02$ & $0.010 \dagger$ \\
\hline & CD8+ TEM 3 & $-1.81 \pm 0.87$ & $0.06 \pm 0.04$ & $0.007 \dagger$ \\
\hline
\end{tabular}

Columns show (1) marker name, (2) men and (3) women MRD \pm sigma, and (4) $p$ value. The statistical significance is achieved when $p<0.05^{\dagger}$. Data are expressed as mean \pm sigma. Statistical differences between men and women patients were evaluated using Student's $t$ tests

course of HIV infection. Despite the successful HIV suppression achieved with ART and the related meaningful benefits, some significant limitations of therapy are progressively emerging: the persistence of the generalized state of chronic immune activation and inflammation, linked to serious non-AIDS, events are among the most significant [20]. These conditions are the result of several factors mainly including dysbiosis, impairment of the gut mucosa and local and general immunity, persistent antigen stimulation due to microbial translocation and low residual viremia, co-infection-related damages, and cumulative ART toxicity [21].

Similarly to what has already been reported for HIVnegative patients, sex represents a significant variable capable of impacting also in the setting of HIV disease. Significant differences in the clinical history of HIV infection have been reported between females and males, with women experiencing an increased risk of developing AIDS compared to men for similar level of HIVRNA and lower baseline viral load in primary infection. Despite sex specific differences in HIV, pathogenesis are yet poorly understood, and devoted studies are lacking; to explain this fact, it has been hypothesized that a less intense immune activation in HIV-infected males than in females could explain why men progress to AIDS at the same rate as or slower than women. In fact, some preliminary studies have observed that the greatest production of IFN- $\alpha$ by dendritic cells in response to HIV stimulation, observed in women, is associated to progesterone levels. At the same time, the intensity of immune activation seems to be directly related with IFN- $\alpha$ levels, which, in turn, are a risk factor for the HIV progression regardless of the viral load in chronic stage of HIV infection $[14,22-25]$.

In light of these preliminary evidences, we investigated possible sex-specific differences in immune activation markers on T-cells derived from peripheral blood and intestinal mucosa. All subjects enrolled in the analysis had undetectable plasma viremia, relatively high CD4 Tcell counts, and no differences in terms of clinical presentation and previous antiretroviral regimen were noted between men and women. Overall, in our study, the levels of immune activation were higher in the gut than in the PBMCs. However, when we analyzed by sex, we observed that immune activation markers expressed on CD4+ and CD8+ $\mathrm{T}$ cells were statistically significantly higher in women than in men both in the gut and in PBMCs. Moreover, women showed more impressive alterations in the gut mucosal T-cell repertoire, especially in the Th1, Th17, and Th1/Th17 cell subsets with central or effector memory phenotype, compared to blood district than their men counterpart. Functionally, these femalespecific cell subset alterations might explain gender differences described in clinical presentation and outcomes of HIV infection $[26,27]$ and confirm previous observations showing that IL-17-expressing T-cell subset frequencies in PBMC differ from those found in the gut $[27,28]$. Sex-related differences in hormonal setting 


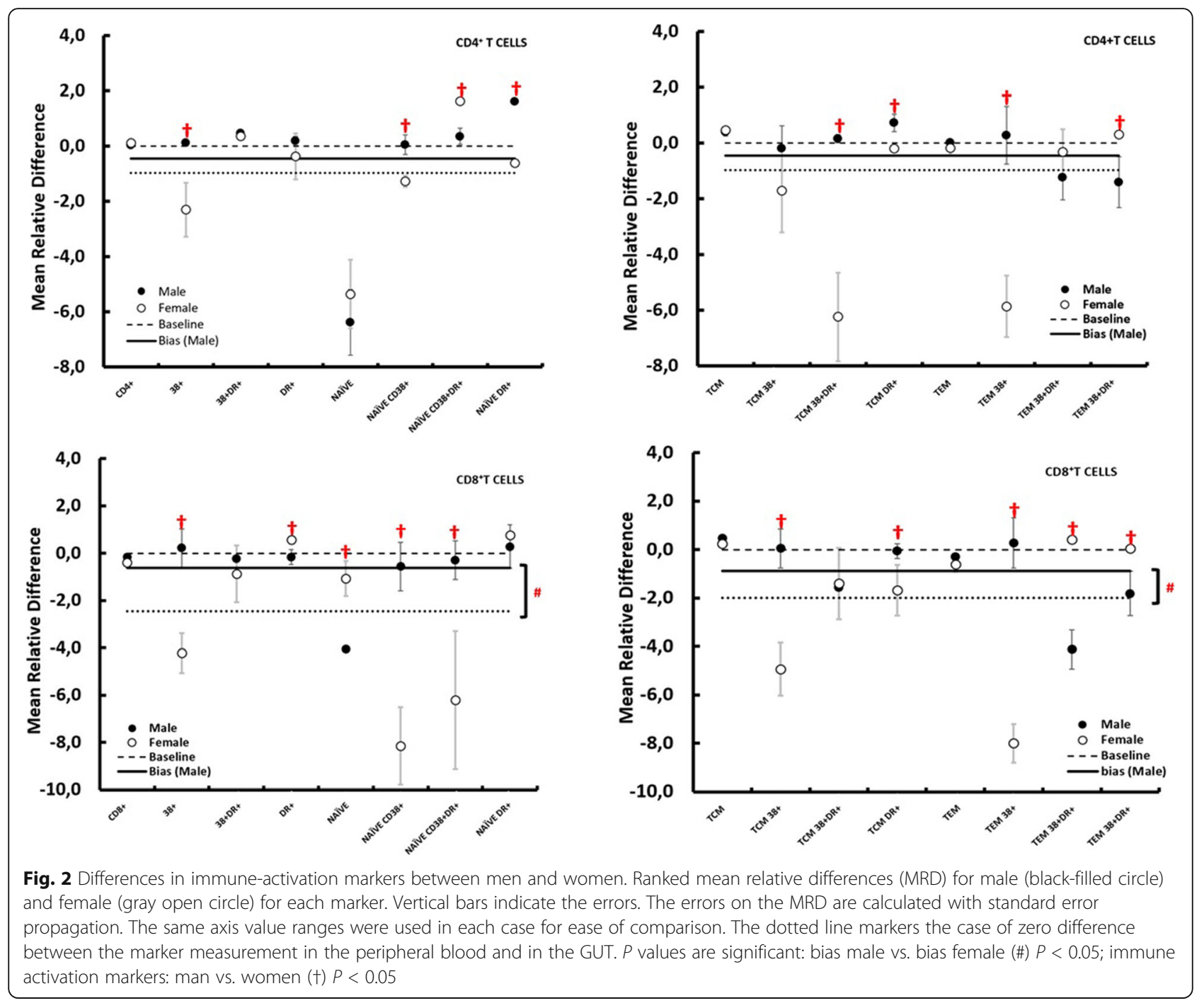

Table 5 Multivariate analysis of factors associated with HIV-1-infection

\begin{tabular}{|c|c|c|c|c|}
\hline \multirow[t]{2}{*}{ Parameters } & \multirow{2}{*}{$\begin{array}{l}\text { Female } \\
n(\mathrm{n} \%)\end{array}$} & \multirow{2}{*}{$\begin{array}{l}\text { Male } \\
n(\mathrm{n} \%)\end{array}$} & \multicolumn{2}{|c|}{ Multivariate analysis } \\
\hline & & & OR (95\%Cl) & $p$ value $(+)$ \\
\hline Age (< 45 years) & $2(13)$ & $5(33)$ & $0.3(0.1-1.9)$ & 0.208 \\
\hline Smokers & $7(47)$ & $11(73)$ & $0.7(0.2-2.7)$ & 0.629 \\
\hline Years on ART (> 3 years) & $9(60)$ & $10(67)$ & $0.81(0.2-2.8)$ & 0.752 \\
\hline Years HIV diagnosis (> 3 years) & $9(60)$ & $10(67)$ & $0.81(0.2-2.8)$ & 0.752 \\
\hline \multicolumn{5}{|l|}{ CD4 NADIR } \\
\hline$<200$ cells $/ \mathrm{mm}^{3}$ & $3(20)$ & $6(40)$ & $0.4(0.1-1.9)$ & 0.239 \\
\hline 200-500 cells $/ \mathrm{mm}^{3}$ & $3(20)$ & $5(33)$ & $0.5(0.1-2.6)$ & 0.413 \\
\hline$>500$ cells $/ \mathrm{mm}^{3}$ & $9(60)$ & $4(27)$ & $4.1(0.9-19.2)$ & 0.071 \\
\hline HCV infection & $1(7)$ & $2(13)$ & $0.46(0.1-5.7)$ & 0.550 \\
\hline
\end{tabular}

(+)Statistical significance shown if $95 \% \mathrm{Cl}$ does not include 1 OR odds ratio, $95 \% \mathrm{Cl}$ 95\% Confidence level, HCV hepatitis C virus 
probably play a pivotal role in this context with estrogen levels able to modulate CD4+ and CD8+ T cells subsets including Th1, Th2, Th17, and to influence several cytokines (TNF- $\alpha$, IL-12, IL-6, IL-1 $\beta$, IL-21) strictly related to the Th1/Tc1 and Th17/Tc17 response [29-34]. Taken together, these data might suggest that the gut T-cell environment could be a more sensitive site for HIV infection in women than in men, considering that both Th1/ Th17 cells represent a preferred site for HIV-DNA longterm persistence and human lamina propria CD4+ $\mathrm{T}$ cells are naturally permissive to HIV-1 infection $[35,36]$.

The possible biases, represented by the higher duration of ART therapy observed in women enrolled along with potentially other HIV-related variables, were considered in a multivariate modeling: analysis showed that in our study sex remained as an independent predictor of difference in immune cell levels in the gut and periphery.

Interestingly, in our study, all women showed signs of premature aging (i.e., early menopause and lower levels of bone mineral density). Our hypothesis is that the persistence of higher levels of markers of immune activation in the gut of women, compared to men, may drive an accelerated senescence and suggest a different response to ART despite complete virological suppression. In this regard, a recent study reported the sex-related differences in immune activation and inflammatory markers observed in HIV-1-positive women and men after ART initiation [8]. These authors found higher levels of TNF and IFN $\gamma$ in the women compared to the men after 48 weeks of follow-up, thus confirming the more limited effect of ART on immune activation control in the women [8]. Furthermore, in women with HIV infection, the risk of early menopause is one of the possible manifestations of premature aging, as we have also hypothesized in our cohort. From this point of view, it is interesting to note that despite menopause, PLWH remain a neglected area of study and only limited data is currently available to support a relationship between menopause status and immune activation [37]. Evidence from studies of women with autoimmune conditions supports a role for chronic inflammation in early menopause onset [38]. Notwithstanding, the current lack of data on a direct relationship between immune activation and early onset of menopause in PLWH increased immune activation in older women living with HIV [39]. The association between HIV and earlier age at menopause were reported. In particular, post-menopausal women with HIV infection receiving antiretroviral treatment and who achieved viral suppression are in a generalized status of immune activation compared to uninfected age-matched controls [40]. Moreover, a cross-sectional analysis from the Canadian HIV Women's Sexual and Reproductive Health Cohort Study evidenced that $29.7 \%$ of women experienced menopause < 45 years: $13.1 \%$ with premature menopause and $16.6 \%$ with early menopause [41]. Data was confirmed by a study conducted in a cohort of PLWH in Rio de Janeiro, Brazil: $27 \%$ of women had early menopause also in this report [42]. Finally, in ANRS CO3 Aquitaine cohort, earlier occurrence of menopause was associated both with HIV-related factors, such as a CD4 cell count $<200$ cells $/ \mathrm{mm}$, and factors already reported for HIV-negative women (ethnicity and history of injecting drug use) [43]. In summary, our results do not allow us to say with certainty that the patients enrolled experienced an early menopause linked to the state of persistent immune activation; however, a number of evidences in the literature supports the possibility that chronic inflammation and immune activation could be drivers of early menopause also in PLWH.

It is conceivable that multiple and complex molecular, cellular, and endocrine mechanisms act synergistically in determining these sex-related differences between HIVpositive men and women. Early evidence suggests that sex hormones have an important role in modulating variations of innate and adaptive immune responses to HIV infection [7, 44], and our data underline the fact that these differences in immune activation persist also when women experience menopause.

Considering the fact that hormones cannot completely explain the differences in sex-related immune-activation levels, further hypotheses to explain these differences can be proposed, including genetic (sex chromosomes, microRNAs and long non-coding RNA, genetic polymorphisms) and environmental factors (i.e., nutrition, microbiota, physical activity) [24, 44-46].

This recent progress notwithstanding, there is still a profound knowledge gap on the impact of chromosomal effect on HIV-related immune activation, with only preliminary evidence available on the effects of nutritional status, microbiota, and physical activity in modulating inflammation. Therefore, there is still a need for further studies aimed at understanding the causes and minimizing the higher levels of immune activation observed in females with HIV.

Finally, we found that the levels of several immuneactivation markers (Tables 3 and 4) differ significantly between males and females in the setting of ART-treated HIV infection, thus suggesting the potential clinical utility in monitoring the pro-inflammatory status of male and female individuals with HIV. Regardless of the pathogenetic implications, this difference could represent a useful tool in personalizing the diagnostic measurement of the state of immune activation by defining suitable cutoffs for each individual based on their sex.

This study has several potential biases: the major limitation of this study is the small sample size and the related statistical concerns. Accordingly, the interpretation of the results must be approached with caution. 
Moreover, this study suffers from the availability of data only from a single large academic medical center. For these reasons, the study should be considered as a pilot research and larger studies should be performed to confirm and extend these findings.

\section{Perspectives and significance}

Our data suggest that the higher levels of immune activation observed in female ART-treated subjects with HIV may require the preclinical and clinical evaluation of novel therapeutic strategies aimed at better controlling this immune activation. Moreover, the fact that higher immune activation under ART persists in women longer than in men provides a rationale to consider the possibility of treating HIV-positive individuals with different regimens based on their sex.

\section{Acknowledgements}

None

\section{Human and animal rights}

No animals were used in this research. All humans research procedures were in accordance with the standards set forth in the Declaration of Helsinki principles of 1975, as revised in 2008 (http://www.wma.net/en/20activities/10 ethics/10helsinki/s.

\section{Conflict of interest}

The authors report no conflicts of interest relevant to this article.

\section{Authors' contribution}

L. Santinelli participated in writing the paper, carried out the cytofluorimetric experiments, and analyzed the data. C. Borrazzo performed statistical analysis. G. P. Innocenti, C. Pinacchio, F. Frasca, and C. Nonne carried out the cytofluorimetric experiment. E. N. Cavallari and L. Celani, were responsible for clinical evaluation of the HIV-1 positive patients and performed critical revision of manuscript for intellectual content. G. Ceccarelli participated in writing the paper, was responsible for study concept and design, and supervision and critical revision of manuscript for intellectual content. C. M. Mastroianni and G. d'Ettorre were responsible for the study concept and design, interpretation of data, participated in writing the paper, and performed critical revision of manuscript for intellectual content. All authors reviewed the work and approved the final manuscript.

\section{Funding}

No funding to be declared

\section{Availability of data and materials}

Data are available on request to the corresponding author.

\section{Ethics approval and consent to participate}

The Ethics Committee at "Sapienza" University of Rome approved the study, and all participants provided written informed consent to participate.

\section{Consent for publication}

All participants provided written informed consent for publication

\section{Competing interests}

The authors declare that they have no competing interests.

\section{Author details}

'Department of Molecular Medicine, Sapienza University of Rome, Rome, Italy. ${ }^{2}$ Department of Public Health and Infectious Diseases, Sapienza University of Rome, Rome, Italy.
Received: 25 August 2019 Accepted: 16 April 2020

Published online: 01 May 2020

\section{References}

1. Freeman A, Stanko P, Berkowitz LN, Parnel N, Zuppe A, Bale TL et al. Inclusion of sex and gender in biomedical research: survey of clinical research proposed at the University of Pennsylvania. Biol Sex Differ. 2017:8:22

2. Klein SL, Flanagan KL. Sex differences in immune responses. Nat Rev Immunol. 2016:16(10):626-38.

3. Bhatia A, Sekhon HK, Kaur G. Sex hormones and immune dimorphism. Sci World J [Internet]. 2014 [cited 2018 Jun 25];2014. Available from: https:// www.ncbi.n/m.nih.gov/pmc/articles/PMC4251360/.

4. Enninga EAL, Holtan SG, Creedon DJ, Dronca RS, Nevala WK, Ognjanovic S, et al. Immunomodulatory effects of sex hormones: requirements for pregnancy and relevance in melanoma. Mayo Clin Proc. 2014 Apr;89(4):520-35.

5. Griesbeck M, Scully E, Altfeld M. Sex and gender differences in HIV-1 infection. Clin Sci Lond Engl 1979. 2016 01;130(16):1435-51.

6. Cescon A, Patterson S, Chan K, Palmer AK, Margolese S, Burchell AN, et al. Gender differences in clinical outcomes among HIV-positive individuals on antiretroviral therapy in Canada: a multisite cohort study. PLOS ONE [Internet]. 2013 Dec 31 [cited 2018 Jun 25];8(12). Available from: https:// www.ncbi.n/m.nih.gov/pmc/articles/PMC3877405/.

7. Addo MM, Altfeld M. Sex-based differences in HIV type 1 pathogenesis. J Infect Dis. 2014 Jul 15:209(Suppl 3):S86-92.

8. Mathad JS, Gupte N, Balagopal A, Asmuth D, Hakim J, Santos B, et al. Sexrelated differences in inflammatory and immune activation markers before and after combined antiretroviral therapy initiation. J Acquir Immune Defic Syndr 1999. 2016 01;73(2):123-9.

9. Langford SE, Ananworanich J, Cooper DA. Predictors of disease progression in HIV infection: a review. AIDS Res Ther. 2007 May 14;4:11.

10. Krebs SJ, Slike BM, Sithinamsuwan P, Allen IE, Chalermchai T, Tipsuk S, et al. Sex differences in soluble markers vary before and after the initiation of antiretroviral therapy in chronically HIV infected individuals. AIDS Lond Engl. 2016 Jun 19;30(10):1533-42.

11. Siemens Healthcare Diagnostics Inc., VERSANT HIV-1 RNA 1.5 Assay (kPCR). 2016. Available at https://www.siemens-healthineers.com/siemens_hwemhwem ssxa websites-context-root/wcm/idc/groups/public/@global/@lab/ @moldiag/documents/download/mdaz/ nje4/ edisp/161005-xc1-hiv-1-5assay-spec-sheet-121316-final-03618986.pdf (last access on 21 Jan 2020).

12. Altman D, Machin D, Bryant T, Gardner M. Statistics with confidence: confidence intervals and statistical guidelines: John Wiley and Sons; 2013.

13. Sherman S. Defining the menopausal transition. Am J Med. 2005 Dec 19; 118(Suppl 12B):3-7.

14. Ziegler S, Altfeld M. Sex differences in HIV-1-mediated immunopathology. Curr Opin HIV AIDS. 2016 Mar;11(2):209-15.

15. Ortona E, Pierdominici M, Maselli A, Veroni C, Aloisi F, Shoenfeld Y. Sexbased differences in autoimmune diseases. Ann Ist Super Sanita. 2016 AprJun;52(2):205-12.

16. Fairweather D, Frisancho-Kiss S, Rose NR. Sex differences in autoimmune disease from a pathological perspective. Am J Pathol. 2008 Sep:173(3):600-9.

17. Gracey E, Yao Y, Green B, Qaiyum Z, Baglaenko Y, Lin A, Anton A, Ayearst R, Yip P, Inman RD. Sexual dimorphism in the Th17 signature of ankylosing spondylitis. Arthritis Rheumatol. 2016 Mar;68(3):679-89.

18. Pan F, Tang W, Zhou Z, Gilkeson G, Lang R, Jiang W. Intestinal macrophages in mucosal immunity and their role in systemic lupus erythematosus disease. Lupus. 2018 Oct;27(12):1898-1902).

19. Breton G, Chomont N, Takata H, Fromentin R, Ahlers J, Filali-Mouhim A, Riou C, Boulassel MR, Routy JP, Yassine-Diab B, Sékaly RP. Programmed death-1 is a marker for abnormal distribution of naive/memory $T$ cell subsets in HIV-1 infection. J Immunol. 2013 Sep 1;191(5):2194-204.

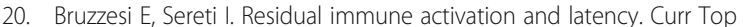
Microbiol Immunol. 2018;417:157-80.

21. Zicari S, Sessa L, Cotugno N, Ruggiero A, Morrocchi E, Concato C, Rocca S, Zangari P, Manno EC, Palma P. Immune activation, inflammation, and nonAIDS co-morbidities in HIV-infected patients under long-term ART. Viruses. 2019 Feb 27:11(3). pii: E200.

22. Meier A, Chang JJ, Chan ES, Pollard RB, Sidhu HK, Kulkarni S, Wen TF, Lindsay RJ, Orellana L, Mildvan D, Bazner S, Streeck H, Alter G, Lifson JD, Carrington M, Bosch RJ, Robbins GK, Altfeld M. Sex differences in the Tolllike receptor-mediated response of plasmacytoid dendritic cells to HIV-1. Nat Med. 2009 Aug;15(8):955-9. 
23. Castilho $J$, Melekhin W, Sterling TR. Sex differences in HIV outcomes in the highly active antiretroviral therapy era: a systematic review. AIDS Res Hum Retroviruses. 2014 May 1;30(5):446-56.

24. Ziegler SM, Altfeld M. Human immunodeficiency virus 1 and type I interferons —where sex makes a difference. Front Immunol [Internet]. 2017 Sep 28 [cited 2018 Jun 25];8. Available from: https://www.ncbi.n/m.nih.gov/ pmc/articles/PMC5625005/.

25. Dapp MJ, Kober KM, Chen L, Westfall DH, Wong K, Zhao H, et al. Patterns and rates of viral evolution in HIV-1 subtype $B$ infected females and males. Plos One. 2017:12(10):e0182443.

26. Wang $H$, Kotler DP. HIV enteropathy and aging: gastrointestinal immunity, mucosal epithelial barrier, and microbial translocation. Curr Opin HIV AIDS. 2014;9(4):309-16. https://doi.org/10.1097/COH.0000000000000066.

27. d'Ettorre G, Ceccarelli G, Andreotti M, et al. Analysis of Th17 and Tc17 Frequencies and antiviral defenses in gut-associated lymphoid tissue of chronic HIV-1 positive patients. Mediators Inflamm. 2015;2015:395484. https://doi.org/10.1155/2015/395484.

28. Brenchley JM, Paiardini M, Knox KS, et al. Differential Th17 CD4 T-cell depletion in pathogenic and nonpathogenic lentiviral infections. Blood. 2008;112(7):2826-35. https://doi.org/10.1182/blood-2008-05-159301.

29. Khan D, Ansar AS. The immune system is a natural target for estrogen action: opposing effects of estrogen in two prototypical autoimmune diseases. Front Immunol. 2015;6:635. https:/doi.org/10.3389/fimmu.2015.00635.

30. Lélu K, Laffont S, Delpy L, et al. Estrogen receptor a signaling in $T$ lymphocytes is required for estradiol-mediated inhibition of Th1 and Th17 cell differentiation and protection against experimental autoimmune encephalomyelitis. J Immunol Baltim Md 1950. 2011;187(5):2386-2393. doi: 10.4049/jimmunol.1101578.

31. Priyanka HP, Krishnan HC, Singh RV, Hima L, Thyagarajan S. Estrogen modulates in vitro T cell responses in a concentration- and receptordependent manner: effects on intracellular molecular targets and antioxidant enzymes. Mol Immunol. 2013;56(4):328-39. https://doi.org/10. 1016/j.molimm.2013.05.226

32. Robinson DP, Hall OJ, Nilles TL, Bream JH, Klein SL. 17ß-estradiol protects females against influenza by recruiting neutrophils and increasing virusspecific CD8 T cell responses in the lungs. J Virol. 2014;88(9):4711-20. https://doi.org/10.1128/JVl.02081-13.

33. Karpuzoglu-Sahin E, Zhi-Jun Y, Lengi A, Sriranganathan N, Ansar AS. Effects of long-term estrogen treatment on IFN-gamma, IL-2 and IL-4 gene expression and protein synthesis in spleen and thymus of normal C57BL/6 mice. Cytokine. 2001;14(4):208-17. https://doi.org/10.1006/cyto.2001.0876.

34. Gonzalez SM, Taborda NA, Rugeles MT. Role of different subpopulations of CD8+ T cells during HIV exposure and infection. Front Immunol. 2017;8. https://doi.org/10.3389/fimmu.2017.00936.

35. Lapenta C, Parlato S, Spada M, et al. Human lymphoblastoid CD4+ T cells become permissive to macrophage-tropic strains of human immunodeficiency virus type 1 after passage into severe combined immunodeficient mice through in vivo upregulation of CCR5: in vivo dynamics of CD4+ T-cell differentiation in pathogenesis of AIDS. J Virol. 1998;72(12):10323-7.

36. Sun H, Kim D, Li X, et al. Th1/17 Polarization of CD4 T cells supports HIV-1 persistence during antiretroviral therapy. J Virol. 2015;89(22):11284-93. https://doi.org/10.1128/JVI.01595-15.

37. Schnall R, Jia H, Reame N. Association between HIV symptom burden and inflammatory cytokines: an analysis by sex and menopause stage. J Womens Health (Larchmt). 2020 Jan;29(1):119-27.

38. Bertone-Johnson ER, Manson JE, Purdue-Smithe AC, Hankinson SE, Rosner BA, Whitcomb BW. A prospective study of inflammatory biomarker levels and risk of early menopause. Menopause. 2019 Jan;26(1):32-8.

39. Tariq S, Delpech $V$, Anderson J. The impact of the menopause transition on the health and wellbeing of women living with HIV: a narrative review. Maturitas. 2016 Jun;88:76-83.

40. Alcaide ML, Parmigiani A, Pallikkuth S, Roach M, Freguja R, Della Negra M, Bolivar H, Fischl MA, Pahwa S. Immune activation in HIV-infected aging women on antiretrovirals--implications for age-associated comorbidities: a cross-sectional pilot study. PLoS One. 2013 May 28;8(5):e63804.

41. Andany N, Kaida A, de Pokomandy A, Yudin MH, Wang L, Kennedy VL, Webster K. Loutfy M; CHIWOS Research Team. Prevalence and correlates of early-onset menopause among women living with HIV in Canada. Menopause. 2020 Jan;27(1):66-75.
42. Calvet GA, Grinsztejn BG, Quintana Mde S, Derrico M, Jalil EM, Cytryn A, de Andrade AC, Moreira Rl, Alves MR, Veloso Dos Santos VG, Friedman RK. Predictors of early menopause in HIV-infected women: a prospective cohort study. Am J Obstet Gynecol. 2015 Jun;212(6):765.e1-765.e13.

43. de Pommerol M, Hessamfar M, Lawson-Ayayi S, Neau D, Geffard S, Farbos S, Uwamaliya B, Vandenhende MA, Pellegrin JL, Blancpain S, Dabis F. Morlat P; Groupe d'Epidémiologie Clinique du SIDA en Aquitaine (GECSA). Menopause and HIV infection: age at onset and associated factors, ANRS CO3 Aquitaine cohort. Int J STD AIDS. 2011 Feb;22(2):67-72.

44. Scully EP. Sex differences in HIV infection. Curr HIV/AIDS Rep. 2018;15(2): 136-46.

45. Siddiqui RA, Sauermann U, Altmüller J, Fritzer E, Nothnagel M, Dalibor N, et al. X chromosomal variation is associated with slow progression to AIDS in HIV-1-infected women. Am J Hum Genet. 2009 Aug;85(2):228-39.

46. Nazli A, Dizzell S, Zahoor MA, Ferreira VH, Kafka J, Woods MW, et al. Interferon- $\beta$ induced in female genital epithelium by HIV-1 glycoprotein 120 via Toll-like-receptor 2 pathway acts to protect the mucosal barrier. Cell Mol Immunol. 2018 Mar;19.

\section{Publisher's Note}

Springer Nature remains neutral with regard to jurisdictional claims in published maps and institutional affiliations.
Ready to submit your research? Choose BMC and benefit from:

- fast, convenient online submission

- thorough peer review by experienced researchers in your field

- rapid publication on acceptance

- support for research data, including large and complex data types

- gold Open Access which fosters wider collaboration and increased citations

- maximum visibility for your research: over $100 \mathrm{M}$ website views per year

At $\mathrm{BMC}$, research is always in progress.

Learn more biomedcentral.com/submissions 